\title{
Adaptive response of Schizosaccharomyces pombe to hydrogen peroxide and menadione
}

\author{
Joon Lee, ${ }^{1}$ lan W. Dawes ${ }^{2}$ and Jung-Hye Roe ${ }^{1}$ \\ Author for correspondence: Jung-Hye Roe. Tel: +822880 6706. Fax: +8228884911. \\ e-mail: jhroe@alliant.snu.ac.kr
}

\footnotetext{
1 Department of Microbiology, College of Natural Sciences and Research Center for Molecular Microbiology, Seoul National University, Seoul 151-742, Korea

2 School of Biochemistry and Molecular Genetics, University of New South Wales, Sydney, NSW 2052, Australia
}

\begin{abstract}
The response of Schizosaccharomyces pombe to oxidative stresses has been examined. On challenging Schiz. pombe for $60 \mathrm{~min}$ at early exponential phase with either $40 \mathrm{mM} \mathrm{H}_{2} \mathrm{O}_{2}$ or $6 \mathrm{mM}$ menadione (MD), a superoxide-generating agent, less than $10 \%$ of the cells survived. Pretreating Schiz. pombe cells with $0.2 \mathrm{mM} \mathrm{H}_{2} \mathrm{O}_{2}$ or $0.2 \mathrm{mM}$ MD for $1 \mathrm{~h}$ significantly increased survival of these lethal doses of each oxidant, indicating the existence of an adaptive response to oxidative stress. Furthermore, cells pretreated with a low dose of MD became resistant to a lethal dose of $\mathrm{H}_{2} \mathrm{O}_{2}$. However, cells pretreated with $\mathrm{H}_{2} \mathrm{O}_{2}$ became only partially resistant to a lethal dose of MD. Adaptation was accompanied by the induction of several oxidative defence enzymes. The presence of $0.2 \mathrm{mM} \mathrm{H}_{2} \mathrm{O}_{2}$ induced catalase by 2.8 -fold and peroxidase by 2.0 fold. The presence of $0.2 \mathrm{mM}$ MD induced catalase by 2-0-fold, glucose-6phosphate dehydrogenase by 1-9-fold, glutathione reductase by $2 \cdot 7-$ fold, peroxidase by 3-0-fold, and superoxide dismutase (SOD) by $2 \cdot 1$-fold. The higher induction of these defence enzymes by MD may explain why MD-pretreated cells were better adapted to lethal doses of oxidants than $\mathrm{H}_{2} \mathrm{O}_{2}$-pretreated ones. All these enzymes except SOD and peroxidase increased more than 5.0fold as cells proceeded into stationary phase. The GSH/GSSG ratio also increased by $60 \%$. These changes accord with the observation that stationary phase cells survive oxidant treatment better than cells in vegetative growth.
\end{abstract}

Keywords: Schizosaccharomyces pombe, oxidative stress, hydrogen peroxide, menadione, adaptive response

\section{INTRODUCTION}

In order to cope with reactive oxygen species, organisms have evolved appropriate defences. Much progress has been made toward understanding the genetics and physiological responses to oxidative stress, especially in bacteria. Adaptive responses against $\mathrm{H}_{2} \mathrm{O}_{2}$ have been demonstrated in many bacteria (Christman et al., 1985; Bol \& Yasbin, 1990; Lee et al., 1993), in Saccharomyces cerevisiae (Collinson \& Dawes, 1992; Jamieson, 1992) and in mammalian cells (Spitz et al., 1987). The global response to oxidative stress is best understood in Escherichia coli and Salmonella typhimurium (Farr \& Kogoma, 1991; Storz et al., 1990b) in which special regulators and/or redox sensors such as OxyR and SoxR respond to $\mathrm{H}_{2} \mathrm{O}_{2}$ or the superoxide

Abbreviations: MD, menadione (2-methyl-1,4-naphthoquinone); G6PD, glucose-6-phosphate dehydrogenase; GR, glutathione reductase; SOD, superoxide dismutase radical, respectively (Storz et al., 1990a; Hidalgo \& Demple, 1994). Other bacteria also have redox-controlled regulator-sensor systems (Allen, 1993). Several antioxidant enzymes are known to be under the control of these regulators. Hydroperoxidase I (HPI, encoded by kat $G)$ and a subunit of alkylhydroperoxide reductase (encoded by $a b p F$ ) of $E$. coli are induced in an OxyRdependent manner. MnSOD (encoded by $\operatorname{sod} A$ ) and glucose-6-phosphate dehydrogenase (encoded by zwf) are induced by the superoxide radical through SoxRS (Farr \& Kogoma, 1991; Storz et al., 1990b). Antioxidant enzymes are also regulated by other stresses including starvation (Mukhopadhyay \& Schellihorn, 1994) and heat shock (Christman et al., 1985).

As a model eukaryote, Sacch. cerevisiae has been studied and shown to possess adaptation mechanisms against oxidative treatment (Collinson \& Dawes, 1992; Jamieson, 1992; Flattery-O'Brien et al., 1993) and to regulate antioxidant enzymes (Schnell et al., 1992; Gralla \& 
Kosman, 1992; Galiazzo \& Labbe-Bois, 1993). Two catalases of Sacch. cerevisiae, a cytosolic catalase T (encoded by $C T T 1$ ) and a peroxisomal catalase $\mathrm{A}$ (encoded by $C T A 1)$, are regulated by both $\mathrm{O}_{2}$ (Hörtner $e$ t al., 1982) via the transcription factor Hap1 (Zitomer \& Lowry, 1992) and nutrients (Ruis \& Hamilton, 1992). Both superoxide dismutases (SODs) in Sacch. cerevisiae (cytoplasmic $\mathrm{Cu} /$ $\mathrm{ZnSOD}$ and mitochondrial MnSOD) are induced by paraquat, a redox cycling agent (Galiazzo \& Labbe-Bois, 1993). $\mathrm{H}_{2} \mathrm{O}_{2}$ can also induce $\mathrm{Cu} / \mathrm{ZnSOD}$ in this organism (Schnell et al., 1992). Yap1, a yeast homologue of mammalian AP-1, is known to activate the TRX2 gene encoding thioredoxin (Kuge \& Jones, 1994), its action increasing resistance to peroxide stress (Schnell et al., 1992).

Since the fission yeast Scbizosaccharomyces pombe obtains energy via respiration or fermentation it, like Sacch. cerevisiae, may encounter either hypo- or hyperoxic conditions (McDonald \& Tsai, 1989). Here, we report the characteristics of adaptation against oxidative treatment with either $\mathrm{H}_{2} \mathrm{O}_{2}$ or menadione, a superoxide-generating agent in fission yeast, and the levels of induction of antioxidant enzymes in response to these oxidants. We also show that various growth conditions change the levels of these enzymes and the GSH/GSSG ratio, which in turn may affect the resistance of cells to oxidative stresses.

\section{METHODS}

Yeast strains, media and chemicals. Scbiz. pombe strain ED665 $\left(\mathrm{h}^{-}\right.$, ade6-M210 leu1-32 ura4-D18) was kindly provided by $\mathrm{Dr}$ Kyung-Hun Kim (Kangwon National University, Korea). Sacch. cerevisiae strain BWG1-7A (MATa leu2-3 leu2-112 bis4-519 ade $1-100$ ura3-52) was used. YEPD medium containing $1 \%$ $(\mathrm{w} / \mathrm{v})$ yeast extract (Difco), $2 \%(\mathrm{w} / \mathrm{v})$ bacto-peptone (Difco), and $2 \%(\mathrm{w} / \mathrm{v})$ dextrose (Junsei) was used for cell growth. To produce fresh inocula, cells were grown in YES medium (Moreno et al., 1991; 0.5\% yeast extract, 3\% dextrose, $250 \mathrm{mg}$ supplements $\mathrm{l}^{-1}$ ) overnight. All the chemicals used for assay of antioxidant enzymes were obtained from Sigma. Glutathione reductase (EC 1.6.4.2) for determination of cellular glutathione concentrations was also from Sigma and 2-vinylpyridine was purchased from Aldrich.

Determination of survival rates. Cells were grown to an $\mathrm{OD}_{595}$ of $0 \cdot 15$, which corresponds to about $2 \cdot 4 \times 10^{6}$ viable cells $\mathrm{ml}^{-1}$, and harvested by centrifugation at $5000 \mathrm{~g}$ for $5 \mathrm{~min}$. They were resuspended in $100 \mathrm{mM}$ potassium phosphate buffer $(\mathrm{pH} 7 \cdot 0)$ to the same cell density and treated with oxidants at various concentrations. At 20 min intervals, aliquots were taken, diluted in $50 \mathrm{mM}$ potassium phosphate buffer and plated on YES agar plates in duplicate. To monitor adaptation, cells were pretreated with an appropriate concentration of oxidants in YEPD medium for $60 \mathrm{~min}$ at $30^{\circ} \mathrm{C}$ with shaking. They were harvested, resuspended in $100 \mathrm{mM}$ potassium phosphate buffer and challenged with higher concentrations of oxidants. Aliquots were taken at $15 \mathrm{~min}$ intervals, diluted and plated on YES agar in duplicate. To monitor the survival of cells from different growth phases, samples of a culture were taken at an $\mathrm{OD}_{595}$ of 0.15 for early exponential phase, an $\mathrm{OD}_{595}$ of 2.5 for late exponential phase and $72 \mathrm{~h}$ after inoculation $\left(\mathrm{OD}_{595}\right.$ of about $5 \cdot 0)$ for stationary phase. Cells were harvested and washed as above. Cells from later growth phases were diluted in potassium phosphate buffer to an $\mathrm{OD}_{595}$ of about $0 \cdot 15$. Subsequent challenge with oxidant and plating were as above.

Preparation of cell-free extracts. Harvested cells were washed in $10 \mathrm{mM}$ potassium phosphate buffer, resuspended in $50 \mu \mathrm{l}$ $10 \mathrm{mM}$ potassium phosphate buffer containing $1 \mathrm{mM}$ PMSF and disrupted by abrasion with glass beads in Eppendorf tubes using a vortex mixer. Cell debris was removed by two consecutive centrifugations and the amount of protein in the supernatant was determined by the Bradford assay (Bradford, 1976).

Enzyme assays. Catalase activity was determined as described by Beers \& Sizer (1952). The rate of disappearance of $\mathrm{H}_{2} \mathrm{O}_{2}$ was measured spectrophotometrically at $240 \mathrm{~nm}$. One unit of enzyme was defined as the activity that catalyzed the degradation of $1 \mu \mathrm{mol} \mathrm{H}_{2} \mathrm{O}_{2} \mathrm{~min}^{-1}$. The activity of glucose-6-phosphate dehydrogenase (G6PD) was determined according to the protocols outlined by Decker (1977). The rate of reduction of $\mathrm{NADP}^{+}$was monitored by absorption at $340 \mathrm{~nm}$. One unit of enzyme activity was defined as the activity that catalyzed the reduction of $1 \mu \mathrm{mol} \mathrm{NADP}{ }^{+} \mathrm{min}^{-1}$. Glutathione reductase (GR) activity was measured by the procedure of Smith et al.(1988). The assay was based on the reduction of 5,5'-dithiobis(2nitrobenzoic acid) (DTNB) by reduced glutathione (GSH), which is produced by GR. Absorption at $412 \mathrm{~nm}$ was monitored for more than $5 \mathrm{~min}$ to ensure that the crude extract was depleted of any substrates capable of reducing DTNB. Then $1 \mathrm{mM}$ oxidized glutathione (GSSG) was added and the increase in absorption at $412 \mathrm{~nm}$ was measured. One unit of enzyme was defined as the amount of activity that catalysed the production of $1 \mu \mathrm{mol}$ thiobis(2-nitrobenzoic acid) (TNB) $\mathrm{min}^{-1}$. General peroxidase activity was measured spectrometrically by monitoring the oxidation of $o$-dianisidine at $460 \mathrm{~nm}$ in the presence of $\mathrm{H}_{2} \mathrm{O}_{2}$ according to the Decker (1977). One unit of enzyme activity was defined as the activity that increased the $\mathrm{OD}_{460}$ by $0.01 \mathrm{~min}^{-1}$. Total SOD activity was determined by the chemical method based on NADH oxidation described by Paoletti \& Mocali (1993). The reaction mixture contained $40 \mu 17.5 \mathrm{mM}$ $\mathrm{NADH}, 25 \mu \mathrm{l} 100 \mathrm{mM}$ EDTA/50 $\mathrm{mM} \mathrm{MnCl}$, an appropriate amount of extract, and $0.1 \mathrm{ml} 10 \mathrm{mM} \beta$-mercaptoethanol in $0.9 \mathrm{ml}$ triethanolanime/diethanolamine/ $\mathrm{HCl}(100 \mathrm{mM}$ each $)$ buffer. The change at $\mathrm{OD}_{340}$ was recorded for $15 \mathrm{~min}$. The blank was measured in a cuvette where the sample was replaced with an equal volume of buffer. One unit of SOD activity was defined as the amount of enzyme required to inhibit the rate of NADH oxidation of the control by $50 \%$. MnSOD (cyanideinsensitive) was distinguished from $\mathrm{Cu} / \mathrm{ZnSOD}$ activity by inclusion of $2 \mathrm{mM} \mathrm{CN}^{-}$in the assay. SOD activity was calculated using the calibration table presented by Paoletti \& Mocali (1993).

Determination of cellular GSH and GSSG. Cellular levels of GSH and GSSG were determined using GR and 2-vinylpy ridine as described by Griffith (1980). Total glutathione in cell extracts was determined by reducing GSSG to GSH with GR and measuring the rate of reduction of DTNB to TNB by GSH. The amount of GSSG was determined after masking GSH with 2vinylpyridine. A standard curve was obtained by correlating known amounts of glutathione with the rates of DTNB reduction.

\section{RESULTS AND DISCUSSION}

\section{Resistance of Schiz. pombe to oxidative stresses}

Exponentially growing Schiz. pombe cells were treated with various concentrations of $\mathrm{H}_{2} \mathrm{O}_{2}$. Cell survival was not affected significantly by concentrations up to $10 \mathrm{mM}$ 
(a)

(b)

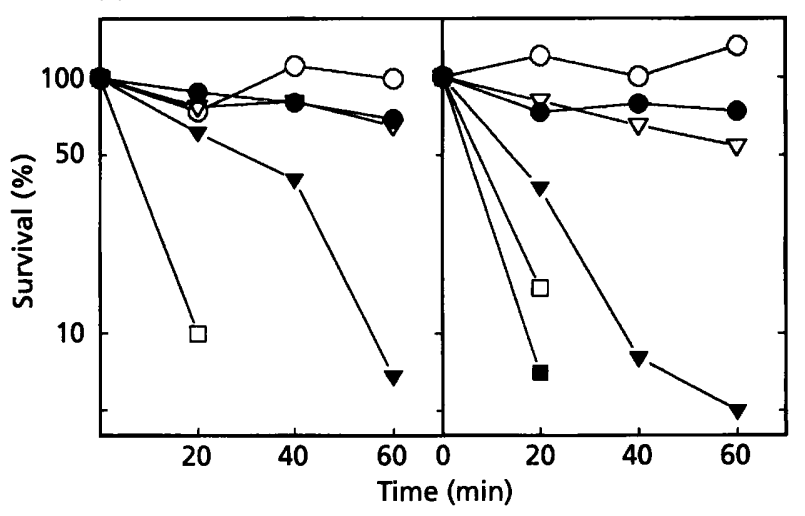

Fig. 1. Survival rates of Schiz. pombe after treatment with $\mathrm{H}_{2} \mathrm{O}_{2}$ or $\mathrm{MD}$. Exponentially growing cells at an $\mathrm{OD}_{595}$ of 0.15 were treated with $\mathrm{H}_{2} \mathrm{O}_{2}$ (a) or MD (b). At 20 min intervals, aliquots were taken and plated on YES in duplicate to monitor cell viability. Concentrations of $\mathrm{H}_{2} \mathrm{O}_{2}$ were $0(0), 0.2(0), 10(\nabla), 40$ $(\nabla)$ or $100 \mathrm{mM}(\square)$. Concentrations of MD were $0(0), 0.2(0)$, $4(\nabla), 6(\nabla), 15(\square)$ or $30 \mathrm{mM}(\square)$. Data are from one representative experiment.

(Fig. 1a). At $40 \mathrm{mM} \mathrm{H}_{2} \mathrm{O}_{2}$, less than $10 \%$ of cells survived after $1 \mathrm{~h}$ of treatment. The requirement for such a high concentration of $\mathrm{H}_{2} \mathrm{O}_{2}$ for killing is unusual compared with other systems. E. coli is killed at a $\mathrm{H}_{2} \mathrm{O}_{2}$ concentration of 1-3 mM, mainly because of DNA damage (Imlay \& Linn, 1988). Streptomyces coelicolor, a strict aerobe, exhibits $1 \%$ survival when treated with $20 \mathrm{mM} \mathrm{H}_{2} \mathrm{O}_{2}$ for $20 \mathrm{~min}$ (Lee et al., 1993). Sacch. cerevisiae shows sensitivity to only about $2 \mathrm{mM} \mathrm{H}_{2} \mathrm{O}_{2}$ (Collinson \& Dawes, 1992; Jamieson, 1992). The resistance of Schiz. pombe to $\mathrm{H}_{2} \mathrm{O}_{2}$ may be partly ascribed to a lack of lipid peroxidation (Janda et al., 1993) and higher levels of several antioxidant enzymes, as well as GSH, as demonstrated below. In contrast, menadione (MD) markedly affected Schiz. pombe cell survival at $6 \mathrm{mM}$ (Fig. 1b), the range of MD concentrations achieving appreciable killing being comparable to that observed for Sacch. cerevisiae (Flattery-O'Brien $e t$ al., 1993).

\section{Adaptation to oxidative stresses}

An organism treated with a nonlethal dose of a stress condition can usually withstand subsequent higher doses of the same stress. Similar adaptation can also result from treatment with different kinds of stresses (Farr \& Kogoma, 1991). To examine whether Schiz. pombe can adapt to oxidative stresses, we tested the effect of sublethal doses of $\mathrm{H}_{2} \mathrm{O}_{2}$ or $\mathrm{MD}$ on the resistance of cells to subsequent exposure to lethal doses of these oxidants. Exponentially growing cells were treated with a sublethal concentration $(0.2 \mathrm{mM})$ of each oxidant for 1 hour in YEPD medium and subsequently treated with a lethal concentration of each oxidant $\left(40 \mathrm{mM} \mathrm{H}_{2} \mathrm{O}_{2}\right.$ or $6 \mathrm{mM}$ MD) in phosphate buffer. Cells pretreated with $\mathrm{H}_{2} \mathrm{O}_{2}$ or MD could tolerate the lethal dose of $\mathrm{H}_{2} \mathrm{O}_{2}$ (Fig. 2a). The extent of resistance was high, which indicates that in the (a)

(b)

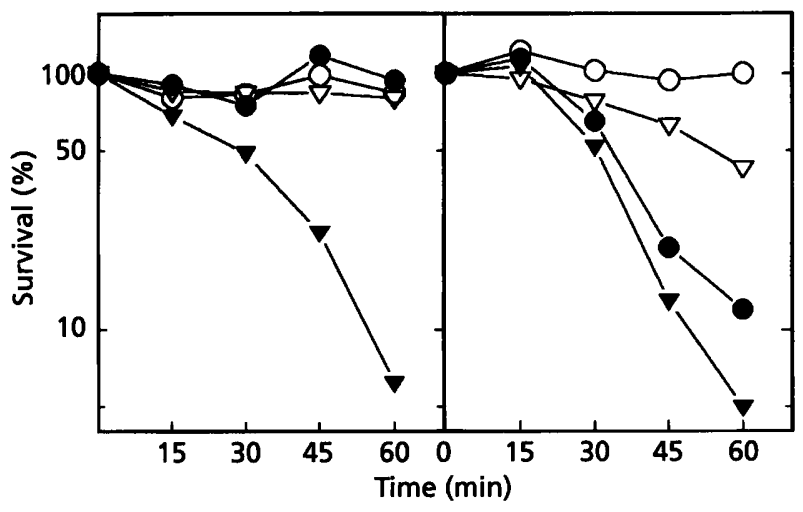

Fig. 2. Adaptation of Schiz. pombe to oxidative stresses. Exponentially growing cells in YEPD medium were not pretreated $(\nabla)$, or were pretreated with $0.2 \mathrm{mM} \mathrm{H}_{2} \mathrm{O}_{2}(O)$ or $0.2 \mathrm{mM} \mathrm{MD}(\nabla)$ for $60 \mathrm{~min}$. They were then challenged with either $40 \mathrm{mM} \mathrm{H} \mathrm{O}_{2}$ (a) or $6 \mathrm{mM} \mathrm{MD}$ (b). At 15 min intervals, aliquots were taken and plated on YES in duplicate. The survival of untreated cells was monitored as a control (O). Data are from one representative experiment.

pretreated cells almost full protection against the applied $\mathrm{H}_{2} \mathrm{O}_{2}$ stress was induced. This demonstrates the existence of an adaptive response by which Scbiz. pombe acquires resistance against $\mathrm{H}_{2} \mathrm{O}_{2}$ stress following pretreatment with either $\mathrm{H}_{2} \mathrm{O}_{2}$ or $\mathrm{MD}$.

In the case of killing with $\mathrm{MD}$, however, the extent of the cellular response to pretreatment with $\mathrm{H}_{2} \mathrm{O}_{2}$ and MD was different (Fig. 2b). Cells pretreated with MD showed relatively high resistance to subsequent challenges with a lethal dose of $\mathrm{MD}$, their survival increasing about 8 -fold. On the other hand, cells pretreated with $\mathrm{H}_{2} \mathrm{O}_{2}$ and then exposed to lethal MD stress showed only a slightly increased resistance (Fig. 2b). This demonstrates that although cells pretreated with each oxidant became more resistant to $\mathrm{MD}$ stress, pretreatment with $\mathrm{H}_{2} \mathrm{O}_{2}$ was not very effective in causing adaptation to $\mathrm{MD}$ stress. Jamieson (1992) observed a similar tendency in Sacch. cerevisiae, although there is also a contradictory report that Sacch. cerevisiae became more resistant to MD stress after pretreatment with $\mathrm{H}_{2} \mathrm{O}_{2}$, but not vice versa (FlatteryO'Brien et al., 1993). If superoxide radicals produced by MD are dismutated into hydrogen peroxide inside the cell, then it is reasonable to propose that superoxide generators can induce a system of protection triggered by $\mathrm{H}_{2} \mathrm{O}_{2}$. This may be why Scbiz. pombe cells treated with a low dose of $\mathrm{MD}$ are fully protected against $\mathrm{H}_{2} \mathrm{O}_{2}$ stress whereas $\mathrm{H}_{2} \mathrm{O}_{2}$-pretreated cells cannot evoke full protection against $\mathrm{MD}$ stress.

The above observations suggest that the superoxide radical, although it probably has some cytotoxic effect, can be a better signalling molecule to prepare cells against oxidative stress in Schiz. pombe. Further investigation of in vivo concentrations of various reactive oxygen species in Schiz. pombe following treatment with $\mathrm{H}_{2} \mathrm{O}_{2}$ or MD is necessary. 
Table 1. Changes in specific activities of oxidative defence enzymes in Schiz. pombe and Sacch. cerevisiae depending on oxidant treatment and growth phase

Cells were grown as described in Methods. Exponentially growing cultures were treated with $0 \cdot 2 \mathrm{mM} \mathrm{H}_{2} \mathrm{O}_{2}$ or $0.2 \mathrm{mM} \mathrm{MD} \mathrm{for} 1 \mathrm{~h}$ and cell-free extracts prepared. The values presented are means \pm SD from 4 independent cultures and are expressed in $U$ (mg protein) ${ }^{-1}$, with the exception of G6PD, which is expressed in $\mathrm{mU}$ ( $\mathrm{mg}$ protein) ${ }^{-1}$.

\begin{tabular}{|c|c|c|c|c|c|c|}
\hline \multirow{3}{*}{$\begin{array}{l}\text { Enzyme } \\
\text { Growth phase... } \\
\text { Oxidant... }\end{array}$} & \multicolumn{5}{|c|}{ Schiz. pombe } & \multirow{3}{*}{$\begin{array}{c}\text { Sacch. cerevisiae } \\
\text { Early exponential } \\
-\end{array}$} \\
\hline & \multicolumn{3}{|c|}{ Early exponential } & \multirow{2}{*}{$\begin{array}{l}\text { Late exponential } \\
-\end{array}$} & \multirow{2}{*}{$\begin{array}{c}\text { Stationary } \\
-\end{array}$} & \\
\hline & - & $\mathbf{H}_{2} \mathbf{O}_{2}$ & MD & & & \\
\hline Catalase & $30 \cdot 0 \pm 4 \cdot 6$ & $84 \cdot 9 \pm 5 \cdot 7$ & $60 \cdot 8 \pm 1.9$ & $98 \cdot 6 \pm 11 \cdot 4$ & $141 \cdot 0 \pm 21 \cdot 0$ & $4.0 \pm 0.5$ \\
\hline G6PD & $33 \cdot 5 \pm 4 \cdot 3$ & $34 \cdot 3 \pm 7 \cdot 2$ & $62 \cdot 1 \pm 2 \cdot 4$ & $97 \cdot 7 \pm 10 \cdot 2$ & $191 \cdot 5 \pm 4 \cdot 0$ & $202 \cdot 6 \pm 12 \cdot 5$ \\
\hline GR & $22 \cdot 3 \pm 1 \cdot 1$ & $27 \cdot 6 \pm 1 \cdot 8$ & $60 \cdot 7 \pm 7 \cdot 8$ & $44.7 \pm 5 \cdot 6$ & $122 \cdot 4 \pm 20 \cdot 3$ & $39 \cdot 7 \pm 5 \cdot 6$ \\
\hline Peroxidase & $3 \cdot 1 \pm 0 \cdot 2$ & $6.2 \pm 0.5$ & $9 \cdot 2 \pm 0.7$ & $4 \cdot 3 \pm 0 \cdot 2$ & $7 \cdot 4 \pm 0 \cdot 4$ & $3.5 \pm 0.2$ \\
\hline SOD & $40 \cdot 3 \pm 5 \cdot 2$ & $45 \cdot 3 \pm 6 \cdot 2$ & $83 \cdot 4 \pm 7 \cdot 5$ & $40 \cdot 0 \pm 7 \cdot 3$ & $39 \cdot 5 \pm 5 \cdot 2$ & $13 \cdot 7 \pm 1 \cdot 3$ \\
\hline
\end{tabular}

\section{Antioxidant enzymes are induced at different levels by $\mathrm{H}_{2} \mathrm{O}_{2}$ and $M D$}

To investigate the mechanism of adaptation, we measured the changes in the levels of several antioxidant enzymes in early exponential phase cells pretreated with sublethal dose of each oxidant (Table 1). Treatment with $0.2 \mathrm{mM}$ $\mathrm{H}_{2} \mathrm{O}_{2}$ induced catalase and peroxidase $2 \cdot 8$ - and $2 \cdot 0$-fold, respectively. The levels of other enzymes increased only marginally. However, the presence of $0.2 \mathrm{mM}$ MD increased the level of these enzymes to a greater extent. Catalase, G6PD and SOD increased approximately 2-fold, whereas GR and peroxidase increased 3-fold. The levels of cyanide-sensitive (possibly $\mathrm{Cu} / \mathrm{ZnSOD}$ ) and cyanideinsensitive (possibly MnSOD) SOD activity increased equally after treatment with MD (data not shown). The greater induction of antioxidant enzymes by $0.2 \mathrm{mM} \mathrm{MD}$ compared to $0.2 \mathrm{mM} \mathrm{H}_{2} \mathrm{O}_{2}$ may be responsible for the better protection against oxidative stress induced by $\mathrm{MD}$ (Fig. 2). The induction of mainly catalase and peroxidase by $0.2 \mathrm{mM} \mathrm{H} \mathrm{H}_{2} \mathrm{O}_{2}$ might be sufficient to protect against a lethal dose of $\mathrm{H}_{2} \mathrm{O}_{2}$, whereas induction of additional enzymes such as G6PD, GR and SOD may be necessary to protect cells against superoxide stress.

The level of the same antioxidant enzymes in Sacch. cerevisiae at early exponential phase was measured (Table 1). Sacch. cerevisiae contained a higher level of G6PD but much lower levels of catalase and SOD. The difference in the level of catalase may explain why Schiz. pombe is more resistant to $\mathrm{H}_{2} \mathrm{O}_{2}$ than Sacch. cerevisiae.

\section{Effects of growth phase on the induction of antioxidant enzymes}

There are reports that bacterial cells and Saccb. cerevisiae acquire higher resistance to various stressful treatments as they proceed into stationary phase (Dowds et al., 1987; Lange \& Hengge-Aronis, 1991; Jamieson, 1992; Steels $e t$ al., 1994). Induction of several antioxidant enzymes was observed to accompany this acquisition of resistance (a)

(b)

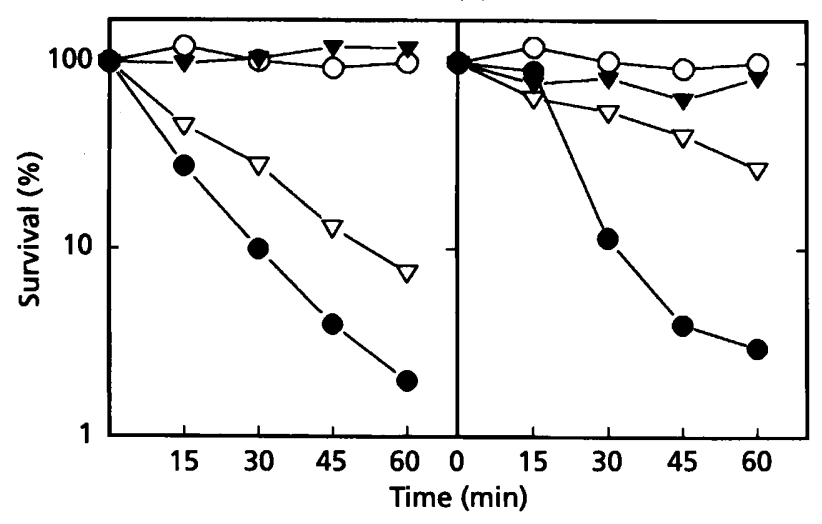

Fig. 3. Survival rates of Schiz. pombe at different growth phases. Cells at early exponential (O), late exponential ( $\nabla$ ) or stationary $(\nabla)$ phase were treated with $40 \mathrm{mM} \mathrm{H}_{2} \mathrm{O}_{2}$ (a) or $6 \mathrm{mM}$ MD (b). At $15 \mathrm{~min}$ intervals following treatment, aliquots were taken and plated on YES in duplicate. The survival of untreated cells was monitored as a control (O). Data are from one representative experiment.

(McCann et al., 1991; Lowen et al., 1985; Belázzi et al., 1991). The survival of Schiz. pombe cells was measured at three different growth stages in YEPD medium following treatment with lethal concentrations of $\mathrm{H}_{2} \mathrm{O}_{2}$ or $\mathrm{MD}$ (Fig. 3 ). In order to exclude the possible effects of cell density on the survival rate, we diluted the cultured cells to the same turbidity at the time of oxidant treatment. An increase in resistance to both $\mathrm{H}_{2} \mathrm{O}_{2}$ and MD was observed as cells proceeded into stationary phase.

The levels of various antioxidant enzymes was also determined in cells at each growth stage, the results being summarized in Table 1. Catalase activity increased up to about 5-fold at stationary phase, which is higher than the amount induced by treatment of cells with $\mathrm{H}_{2} \mathrm{O}_{2}$ or MD. Both G6PD and GR increased up to almost 6-fold as growth proceeded to stationary phase. Peroxidase, on the 
Table 2. Changes in intracellular concentrations of glutathione in Schiz. pombe at different growth phases, and in Sacch. cerevisiae at exponential phase

Cells were grown and cell-free extracts prepared as described in Methods. The values presented are means $\pm S D$ from 4 independent cultures.

\begin{tabular}{|c|c|c|c|}
\hline Strains & Growth phase & $\begin{array}{c}\text { Total } \\
\text { glutathione } \\
\text { concn } \\
{[\text { nmol }(\mathrm{mg}} \\
\text { protein })^{-1} \text { ] }\end{array}$ & $\begin{array}{c}\text { GSH/GSSG } \\
\text { ratio }\end{array}$ \\
\hline Scbiz. pombe & $\begin{array}{l}\text { Early exponential } \\
\text { Late exponential } \\
\text { Stationary }\end{array}$ & $\begin{array}{l}31 \cdot 8 \pm 1 \cdot 2 \\
32 \cdot 0 \pm 3 \cdot 3 \\
35 \cdot 5 \pm 3 \cdot 8\end{array}$ & $\begin{array}{l}22 \cdot 5 \pm 4 \cdot 6 \\
21 \cdot 8 \pm 4 \cdot 4 \\
36 \cdot 0 \pm 4 \cdot 3\end{array}$ \\
\hline Sacch. cerevisiae & Early exponential & $29 \cdot 5 \pm 5 \cdot 9$ & $14 \cdot 7 \pm 2 \cdot 8$ \\
\hline
\end{tabular}

other hand, increased only about 2-fold, whereas SOD remained unchanged as growth proceeded. The change in the level of catalase in our study is consistent with previous observations in Sacch. cerevisiae that catalase $\mathrm{T}$ is induced at the resting state when nutrients become limiting (Belázzi et al., 1991). The insensitivity of SOD to change was further examined by differentiating cyanidesensitive (possibly $\mathrm{Cu} / \mathrm{ZnSOD}$ ) and -insensitive (possibly MnSOD) activity. We found that cyanide-sensitive SOD, which constituted about $80 \%$ of the total SOD in early exponential phase, decreased to almost non-detectable levels as cells proceeded past late exponential phase. In contrast, cyanide-insensitive SOD increased about 6-fold, suggesting that MnSOD levels increase with respiratory adaptation as glucose is exhausted, as also occurs in Sacch. cerevisiae (Galiazzo \& Labbe-Bois, 1933).

The increase of G6PD in the later stage of growth is somewhat surprising, since glucose is exhausted in the stationary phase. Studies with animal cells have demonstrated that fasting cells have lower levels of G6PD whereas refeeding increases its level (Kletzien et al., 1994). In contrast, Schiz. pombe produced higher activities of G6PD under nutrient-limiting conditions. This may contribute to oxidative stress protection, since the G6PD reaction is a major generator of NADPH, providing the reducing equivalents for the regeneration of GSH by GR.

We also measured the level of intracellular glutathione at different growth phases (Table 2). The total amount of glutathione remained unchanged whereas the ratio of GSH to GSSG increased as cells proceeded into stationary phase. This increase in the steady-state level of reduced glutathione correlates with the marked increase in GR and G6PD activity and may contribute to the increased resistance of Schiz. pombe to oxidative stress in the stationary phase (Fig. 3). The higher level of GSH in Schiz. pombe compared to Sacch. cerevisiae may have also contributed to the greater resistance of Schiz. pombe to $\mathrm{H}_{2} \mathrm{O}_{2}$.

From the above results, we conclude that Scbiz. pombe possesses adaptation mechanisms to counter oxidative stress, involving the induction of several antioxidant enzymes. The superoxide-generating compound MD induced more antioxidant enzymes and to a greater extent than $\mathrm{H}_{2} \mathrm{O}_{2}$. The increase in resistance to oxidative stress at later growth phases also correlated well with the increase in these antioxidant enzymes. The involvement of other proteins in protecting Schiz. pombe against oxidation damage as observed in Sacch. cerevisiae needs to be studied further (Collinson \& Dawes, 1992; Jamieson et al., 1994).

\section{ACKNOWLEDGEMENTS}

We thank Dr Kyung-Hun Kim for providing Schiz. pombe strains. This work was supported by a KOSEF Research Grant for the Research Center for Molecular Microbiology in Korea to J.-H. Roe under the collaborative research program between RCMM and the University of New South Wales, Australia. This collaboration was also supported by a grant from the Department of Industry, Trade and Regional Development, Australia.

\section{REFERENCES}

Allen, J. F. (1993). Redox control of transcription: sensors, response regulators, activators and repressors. FEBS Lett 332, 203-207.

Beers, R. F., Jr \& Sizer, I. W. (1952). A spectrophotometric method for measuring breakdown of hydrogen peroxide by catalase. $J$ Biol Chem 195, 276-287.

Belázzi, T., Wieser, R., Schanz, M., Adam, G. \& Ruis, H. (1991). Negative regulation of transcription of the Saccharomyces cerevisiae catalase $\mathrm{T}(C T T 1)$ gene by cAMP is mediated by a positive control element. EMBO J 10, 585-592.

Bol, D. K. \& Yasbin, R. E. (1990). Characterization of an inducible oxidative stress system in Bacillus subtilis. J Bacteriol 172, 3503-3506.

Bradford, M. M. (1976). A rapid and sensitive method for the quantitation of microgram quantities of protein utilizing the principle of protein dye binding. Anal Biochem 72, 248-254.

Christman, M. F., Morgan, R. W., Jacobson, F. S. \& Ames, B. N. (1985). Positive control of a regulon for defences against oxidative stress and some heat-shock proteins in Salmonella typhimurium. Cell 41, 753-762.

Collinson, L. P. \& Dawes, I. W. (1992). Inducibility of the response of yeast cells to peroxide stress. J Gen Microbiol 138, 329-335. 
Decker, L. A. (1977). Wortbington Enzyme Manual. New Jersey, USA : Worthington Biochemical Corporation.

Dowds, B. C. D., Murphy, P., McConnell, D. J. \& Devine, K. M. (1987). Relationship among oxidative stress, growth cycle, and sporulation in Bacillus subtilis. J Bacteriol 169, 5771-5775.

Farr, S. B. \& Kogoma, T. (1991). Oxidative stress responses in Escherichia coli and Salmonella typhimurium. Microbiol Rev 55, 561-585.

Flattery-O’Brien, J., Collinson, L. P. \& Dawes, I. W. (1993). Saccharomyces cerevisiae has an inducible response to menadione which differs from that to hydrogen peroxide. J Gen Microbiol 139, 501-507.

Galiazzo, F. \& Labbe-Bois, R. (1993). Regulation of $\mathrm{Cu}, \mathrm{Zn}$ - and Mn-superoxide dismutase transcription in Saccharomyces cerevisiae. FEBS Lett 315, 197-200.

Gralla, E. B. \& Kosman, D. J. (1992). Molecular genetics of superoxide dismutases in yeast and related fungi. In Advances in Genetics, vol. 30, pp. 251-319. Edited by J. G. Scandalios. San Diego, SF: Academic Press.

Griffith, O.W. (1980). Determination of glutathione and glutathione disulfide using glutathione reductase and 2-vinylpyridine. Anal Biochem 106, 207-212.

Hidalgo, E. \& Demple, B. (1994). An iron-sulfur center essential for transcriptional activation by the redox-sensing SoxR protein. EMBO J 13, 138-146.

Hortner, H., Ammerer, G., Hartter, E., Hamilton, B., Rytika, J., Blinski, T. \& Ruis, H. (1982). Regulation of synthesis of catalase in Saccharomyces cerevisiae by glucose, oxygen and heme. Eur J Biochem 128, 179-184.

Imlay, J. A. \& Linn, S. (1988). DNA damage and oxygen radical toxicity. Science 240, 1302-1309.

Jamieson, D. J. (1992). Saccharomyces cerevisiae has distinctive adaptive responses to both hydrogen peroxide and menadione. J Bacteriol 174, 6678-6681.

Jamieson, D. J., Rivers, S. L. \& Stephen, D. W. S. (1994). Analysis of Saccharomyces cerevisiae proteins induced by peroxide and superoxide stress. Microbiology 140, 3277-3283.

Janda, S., Gill, G., Sigler, K \& Hofer, M. (1993). Effects of peroxidation on sugar transport in Schizosaccharomyces pombe. Absence of membrane lipid peroxidation. Folia Microbiol 38, $135-140$.

Kletzien, R. F., Harris, P. K. W. \& Foellmi, L. A. (1994). Glucose-6phosphate dehydrogenase: a 'housekeeping' enzyme subject to tissue-specific regulation by hormones, nutrients, and oxidative stress. F ASEB J 8, 174-181.

Kuge, S. \& Jones, N. (1994). Y AP1 dependent activation of TRX2 is essential for the response of Saccharomyces cerevisiae to oxidative stress by hydroperoxides. EMBO J 13, 655-664.

Lange, R. \& Hengge-Aronis, R. (1991). Identification of a central regulator of stationary-phase gene expression in Eschericbia coli. Mol Microbiol 5, 49-59.
Lee, J.-S., Hah, Y.-C. \& Roe, J.-H. (1993). The induction of oxidative enzymes in Streptomyces coelicolor upon hydrogen peroxide treatment. $J$ Gen Microbiol 139, 1013-1018.

Lowen, P. C., Switala, J. \& Triggs-Lain, L. (1985). Catalase HPI and HPII in Escherichia coli are inducible independently. Arch Biochem Biophys 243, 144-149.

McCann, M. P., Kidwell, J. P. \& Matin, A. (1991). The putative $\sigma$ factor $\mathrm{KatF}$ has a central role in development of starvationmediated general resistance in Escherichia coli. $J$ Bacteriol 173, 4188-4194.

McDonald, I. J. \& Tsai, C. S. (1989). Continuous culture and intermediary carbon metabolism. In Molecular Biology of the Fission Yeast, pp. 367-397. Edited by A. Nasim, P. Young \& B. Johnson. San Diego, SF: Academic Press.

Moreno, S., Klar, A. \& Nurse, P. (1991). Molecular genetic analysis of fission yeast Schizosaccharomyces pombe. Metbods Envymol 194, 795-823.

Mukhopadhyay, S. \& Schellihorn, H. (1994). Induction of Escherichia coli hydroperoxidase I by acetate and other weak acids. J Bacteriol 176, 2300-2307.

Paoletti, F. \& Mocali, A. (1993). Determination of superoxide dismutase activity by purely chemical system based on NAD(P)H oxidation. In Oxygen Radicals in Biological Systems, pp. 209-221. Edited by L. Packer \& A. N. Glazer. San Diego, SF: Academic Press.

Ruis, H. \& Hamilton, B. (1992). Regulation of yeast catalase genes. In Molecular Biology of Free Radical Scavenging Systems, pp. 153-172. Edited by J. G. Scandalios. Cold Spring Harbor, NY: Cold Spring Harbor Laboratory Press.

Schnell, N., Krems, B. \& Entian, K.-D. (1992). The PAR1 (YAP1/SNQ3) gene of Saccharomyces cerevisiae, a c-jun homologue, is involved in oxygen metabolism. Curr Genet 21, 269-271.

Smith, I. K., Vierheller, T. L. \& Thorne, C. A. (1988). Assay of glutathione reductase in crude tissue homogenates using 5, $5^{\prime}$ dithiobis(2-nitrobenzoic acid). Anal Biochem 175, 408-413.

Spitz, D. R., Dewey, W. C. \& Li, G. C. (1987). Hydrogen peroxide or heat shock induces resistance to hydrogen peroxide in chinese hamster fibroblasts. $J$ Cell Physiol 131, 364-373.

Steels, E. L., Learmonth, R. P. \& Watson, K. (1994). Stress tolerance and membrane lipid unsaturation in Saccharomyces cerevisiae grown aerobically or anaerobically. Microbiology 140, 569-576.

Storz, G., Tartaglia, L. A. \& Ames, B. N. (1990a). Transcriptional regulator of oxidative stress-inducible genes: direct activation by oxidation. Science 248, 189-194.

Storz, G., Tartaglia, L. A., Farr, S. B. \& Ames, B. N. (1990b). Bacterial defences against oxidative stress. Trends Genet 6, 363-368.

Zitomer, R. S. \& Lowry, C. V. (1992). Regulation of gene expression by oxygen in Saccharomyces cerevisiae. Microbiol Rev 56, 1-11.

Received 12 June 1995; revised 1 August 1995; accepted 22 August 1995. 